\author{
Maciej Kaczorek \\ Mgr inż. \\ PKP Polskie Linie Kolejowe S.A., \\ Biuro Strategii i Rozwoju Politechnika Warszawska, Wydział Transportu \\ maciej.kaczorek@plk-sa.pl
}

\author{
Aleksandra Falana \\ Mgr inż. \\ PKP Polskie Linie Kolejowe S.A., Biuro Strategii i Rozwoju \\ aleksandra.falana@plk-sa.pl
}

DOI: 10.35117/A_ENG_18_06_07

\title{
Technical asset management as basis for rational planning of railroad inf rastructure maintenance and development - assumptions and systems review
}

\begin{abstract}
The paper deals with the application of the method and systems for technical asset management in the process of the planning of railroad infrastructure maintenance and development. Due to the scale of operations of rail infrastructure managers, the application of appropriate management methods and IT tools supporting decision making, keeps increasingly resulting in the condition of the effectiveness for this measure. Technical asset management as part of Asset Management is an activity aimed at achieving a balance between factors such as: costs, risk, and efficiency, in such a way so as to meet the objectives of the infrastructure manager. The paper presents assumptions and the most important features with functionalities of systems used to manage technical assets. A review of systems including an assessment of their advanced technology and main implementations in entities related to railroad infrastructure have been presented. As a result of systems review, key areas of future use and related benefits have been identified.
\end{abstract}

Keywords: Technical asset management; Asset management; Railroad infrastructure maintenance; Investment; Railroad infrastructure development

\section{Introduction}

The diagnosis put forward by the authors of the White Paper from 1996 [1] indicates the need to increase the competitiveness of the rail sector towards air and road transport. As the key reason for the steadily decreasing share of railways in transport, in this document, identified, among others unsatisfactory quality and price of services and the general lack of ability of railway undertakings to adapt to the changing requirements of the transport market. The response to these negative phenomena has been the deep reform of the railway system in the European Union. It is based in particular on the separation of infrastructure management implemented so far from transport performance.

However, structural change alone is only an opportunity to improve the efficiency and competitiveness of the rail sector. In this area, it is essential to formulate, by the Member States obliged to finance railway infrastructure [2], requirements for infrastructure managers that stimulate real improvement of functioning. Due to the scale of operations of rail infrastructure managers, the condition of the effectiveness of this measure, however, is the use of appropriate management methods and IT tools supporting decision-making. 


\section{Conditions for the development and maintenance of railway infrastructure}

In Poland, only PKP Polskie Linie Kolejowe S.A. is responsible for enterprises operating in the field of railway infrastructure management in the whole country. The manager of the national railway network on 12/31/2017 ruled, among others, [9]:

- $18.513 \mathrm{~km}$ of operated railway lines,

- 39,482 turnouts,

- 25324 engineering objects,

- 14,442 level crossings,

- 14,108 buildings (including platforms, shelters, acoustic screens)).

The technical condition of the infrastructure over the years 2010-2016 has been gradually improved. However, according to the study of the Office of Rail Transport [6] still, about $45 \%$ of the length of the railway lines is characterized by a technical condition defined as sufficient or unsatisfactory.

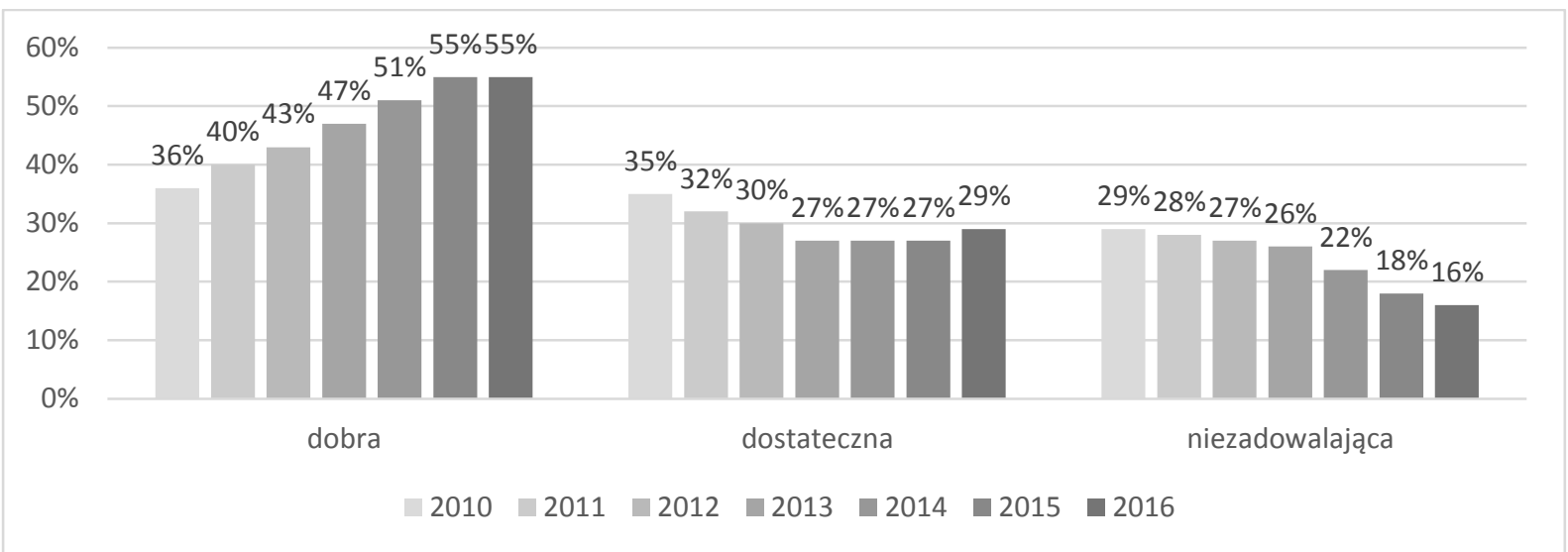

1. Assessment of the technical condition of the railway infrastructure in 2010 - 2016 [6]

The improvement of the technical condition of the railway infrastructure is the result of the increase in the number of public funds directed to the financing of railway infrastructure. These subsidies are directed within two areas:

- Development or investment

and

- operating activities, i.e. maintenance and repairs.

The volume of subsidies as part of operational activities directed to PKP Polskie Linie Kolejowe S.A. as a result of the adoption of the long-term program by the Council of Ministers Assistance in financing the costs of railway infrastructure management, including its maintenance and repairs until 2023 [8], will increase significantly in the period 2019 2023. 


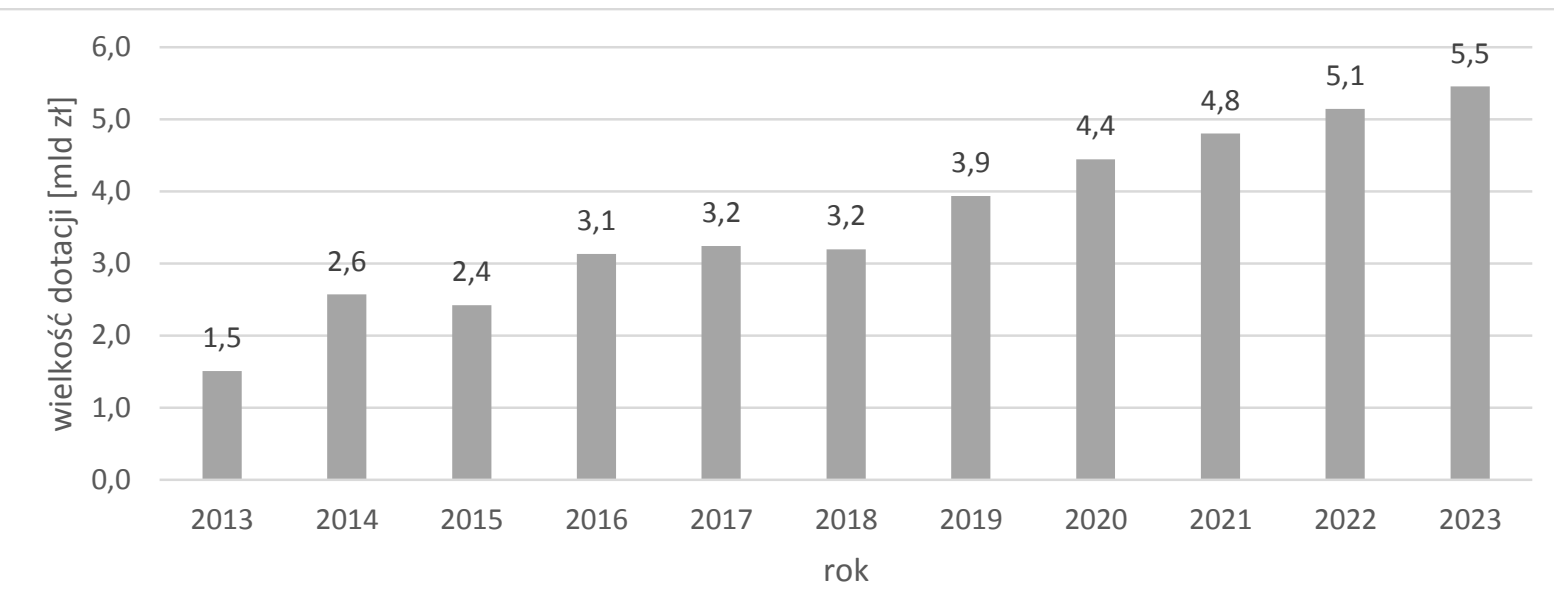

2. The amount of financing the costs of railway infrastructure management in the years 2013$2023[8]$

Similarly, expenditures on development activities included in the National Railway Program until 2023 in the following years will show a significant increase reaching the level of PLN 10 billion annually.

Taking into account the transport policy of Poland and the EU aimed at increasing the share of rail transport in transport, it should be expected that an increase in the level of financing of railway infrastructure will be a permanent phenomenon. In this situation, it becomes particularly important that the spending of funds is based on precise knowledge gathered in the form of efficient use in the analytical process.

Among the key issues for the decision-making process in planning the development and maintenance of infrastructure, the following should be indicated:

- prediction of the technical condition of infrastructure elements,

- costs of renewing these elements.

\section{Assumptions for the use of methods for managing technical assets in the planning process}

Technical asset management as part of Asset Management is an activity aimed at achieving a balance between factors such as:

- costs,

- the risk

-efficiency

in such a way as to achieve the organization's objectives, in this case the railway infrastructure manager.

The formal definition of asset management is contained in the ISO 55000 standard (formerly PAS55) [7]. BSI PAS 55 was created by the Institute of Asset Management, and the first specification of resource management was published in 2004. 23 organizations mainly from the United Kingdom participated in the preparation process. PAS 55 was updated in 2008 with the participation of 49 organizations from 10 countries. The ISO 5500x series standards were published in January 2014 and include:

ISO 55000 Asset management - General information, principles and terminology

ISO 55001 Asset management - Management systems - Requirements

ISO 55002 Asset management - Management systems - Application guidelines ISO 55001

In her mind, asset management is a coordinated approach as a result of which the organization comprehensively manages its infrastructure resources, optimizing efficiency, 
risk, and costs in the perspective of the life cycle of a given asset in order to achieve a strategic vision of the organization and stakeholders. Therefore, it is important to adopt a topdown approach to the implemented resource management system.

Experiences [3, 5] indicate that the well-organized Asset Management provides the following positive effects:

- improvement of overall financial performance,

- better investment decisions,

- better risk management,

- a higher level of services provided to clients,

- greater compliance with legislation and regulations,

- improvement of the organization's reputation.

The foundation of professional resource management is the development of a reliable long-term plan for maintenance and renovation. Planning should include specific work that will serve the overarching strategic goals. The plan should cover the perspective of about 20 years with its scope. It is important that it is developed on the basis of models containing a series of data for all infrastructure elements. The basis for developing the plan are, among others detailed information on resources in all industries, the year of construction, expected time of using infrastructure elements, and information on unit costs. The long-term financing plan should become a tool for determining the number of subsidies granted from the state budget or to demonstrate the difference between the available funding and the number of funds required to achieve the adopted key objectives.

\section{Business Process Management (BPM)}

The basic feature of the professional Asset Management organization is process management, which replaces the task-oriented maintenance and renovation. The implementation of Business Process Management changes the management model focusing on the responsibility for implementation and coordination of tasks without full responsibility for time, cost and scope of work on a process-oriented organization in which managers become responsible for the implementation of these processes with control over implementation and results: sometimes, scope of work, cost. Before implementing BPM, it is reasonable to organize individual processes in a uniform manner throughout the organization. As part of the implementation, it is necessary to define existing processes, establish input data and results to them, assign tasks, competences and responsibilities. Then, processes that need to be optimized should be identified.

\section{Computerization of processes}

An unquestionable feature of professional resource management is computerization of processes. In this area, it is necessary to move from isolated, personal knowledge and information to the knowledge and information made available. This requires several conditions to be met:

- unambiguous structure of resources developed,

- developed a unique method of describing the functionality of infrastructure elements,

- a standardized overview of all possible maintenance and repair activities for each industry.

The use of a comprehensive solution, i.e. implementation of the Enterprise Asset Management system, will lead, among others, to:

- one reliable and complete database of infrastructure elements,

- one source for all information affecting performance,

- one data source for controls and measurements, 
- one reliable long-term financial plan for maintenance and repairs,

- one source of data related to unit maintenance and renovation costs,

- creating a base of information on the completed costs of infrastructure and railway lines,

- creating a database of information on the history of maintenance and repairs,

- implementation of tools for life cycle cost analysis,

- implementation of risk management tools.

In addition, it will be possible to make available, based on the created database, selected information to authorized entities, e.g. for supervisors or carriers.

In the context of the database, it is important to ensure the quality and timeliness of data which is achieved by developing a process of monitoring the status of infrastructure elements and the process of updating the database. Due to the large range of data, it is necessary to use technical solutions for the inventory of railway lines using, for example, photogrammetric data.

\section{The principle of optimization from the perspective of the life cycle}

Life cycle cost analyzes (Life Cycle Costs - LCC) are the basis for choices made by a professional infrastructure manager. Such tools have functionality that allows generation of several variants of approaches to the analyzed case. As a result, it is possible to choose the preferred option, characterized by the best solution in terms of financial outlays and efficiency. This is only possible if you have a database with information about costs and the expected period of use. Life cycle cost analyzes indicate alternatives and are a powerful tool for informing decision-makers on the financial consequences of their actions.

\section{Risk management and its integration with decision-making processes}

The risk defines in a univocal and consistent manner the relationship between costs and effectiveness. Skills and quality of the organization managing the infrastructure allow for an appropriate assessment of the risk impact zone, which affects the optimal implementation of the assumed objectives of the Company. Analyzing risk should be an integral part of making decisions related to maintenance and repairs.

\section{Indicator boards at all levels of the organization}

Efficiency and costs must be managed in a coordinated manner. Therefore, there are necessary tables of indicators to control the efficiency, costs, technical quality in relation to the defined objectives. Indicator boards should be combined with one source of information and calculated automatically.

\section{Continuous development program}

Resource management requires constant development. This is related to the development of management methods, the development of techniques or new tools emerging on the market. The Deming quality cycle is important in the continuous development program: plan, execute, check, correct. These are the main activities thanks to which it will be possible to continuously improve the efficiency and costs in all processes.

In the case of technical property management systems, the decision-making process related to maintenance works is based on the assessment of the technical condition, risk, lifecycle cost of infrastructure elements, and performance indicators of railway lines. This information should also be used in the process of infrastructure development planning, as it allows setting investment priorities and the initial assessment of the required investment expenditures. 


\section{System overview}

Enterprise-class IT solutions for asset management are offered by many software providers. They represent a different degree of complexity of offered functions and advancement. A comprehensive analysis of the offered IT systems has been conducted for many years by the American company Gartner, Inc. This company with almost 40 years of experience uses a magic quadrant method for synthetic evaluation, taking into account a set of unified criteria [4]. This is a universal assessment and for each application, it is required to verify the assessment against the specific goals of the infrastructure manager.

Gartner, Inc. defines four fields of the magic square as shown below.

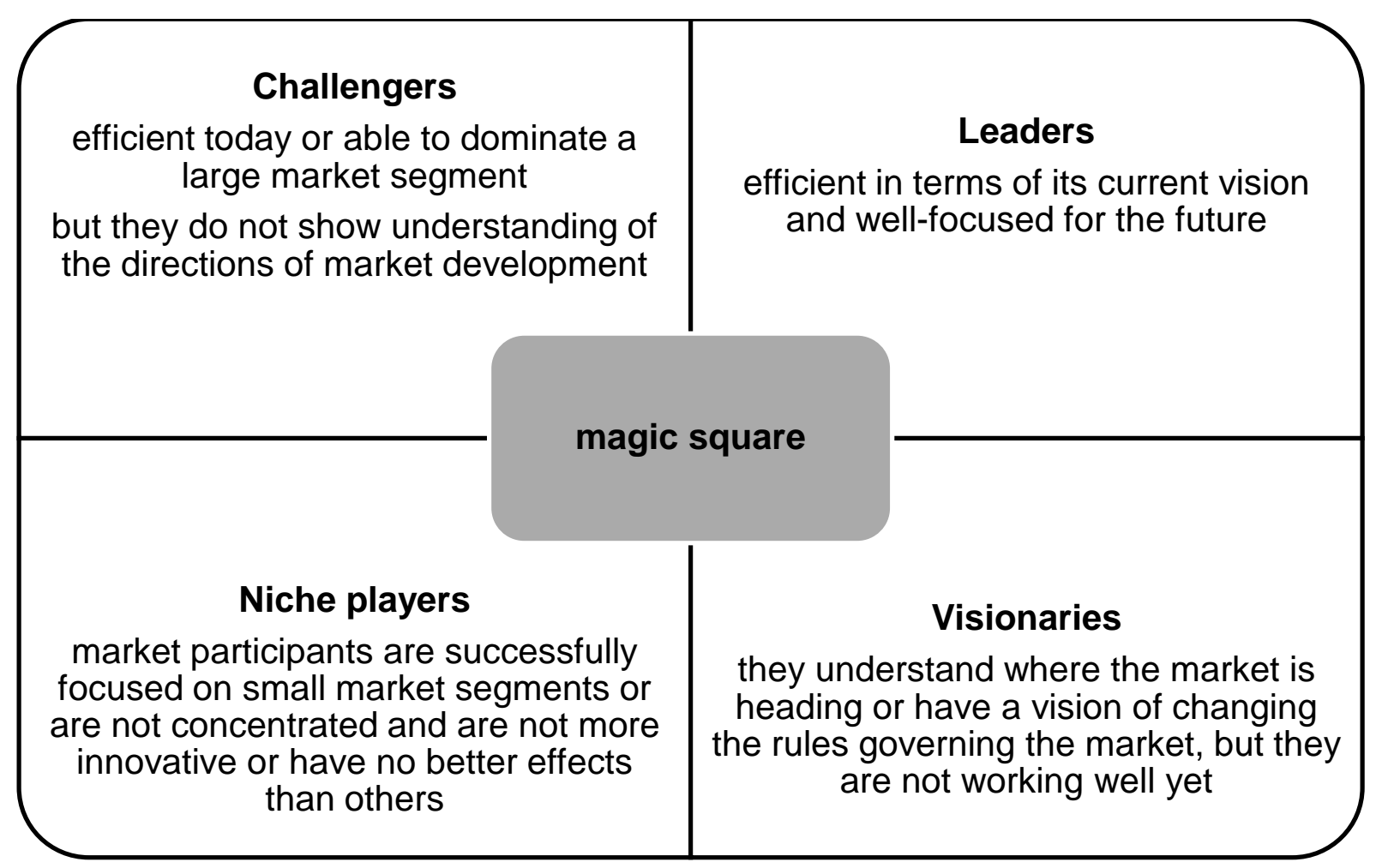

3. Definitions of the magic square fields Gartner, Inc. [4] 


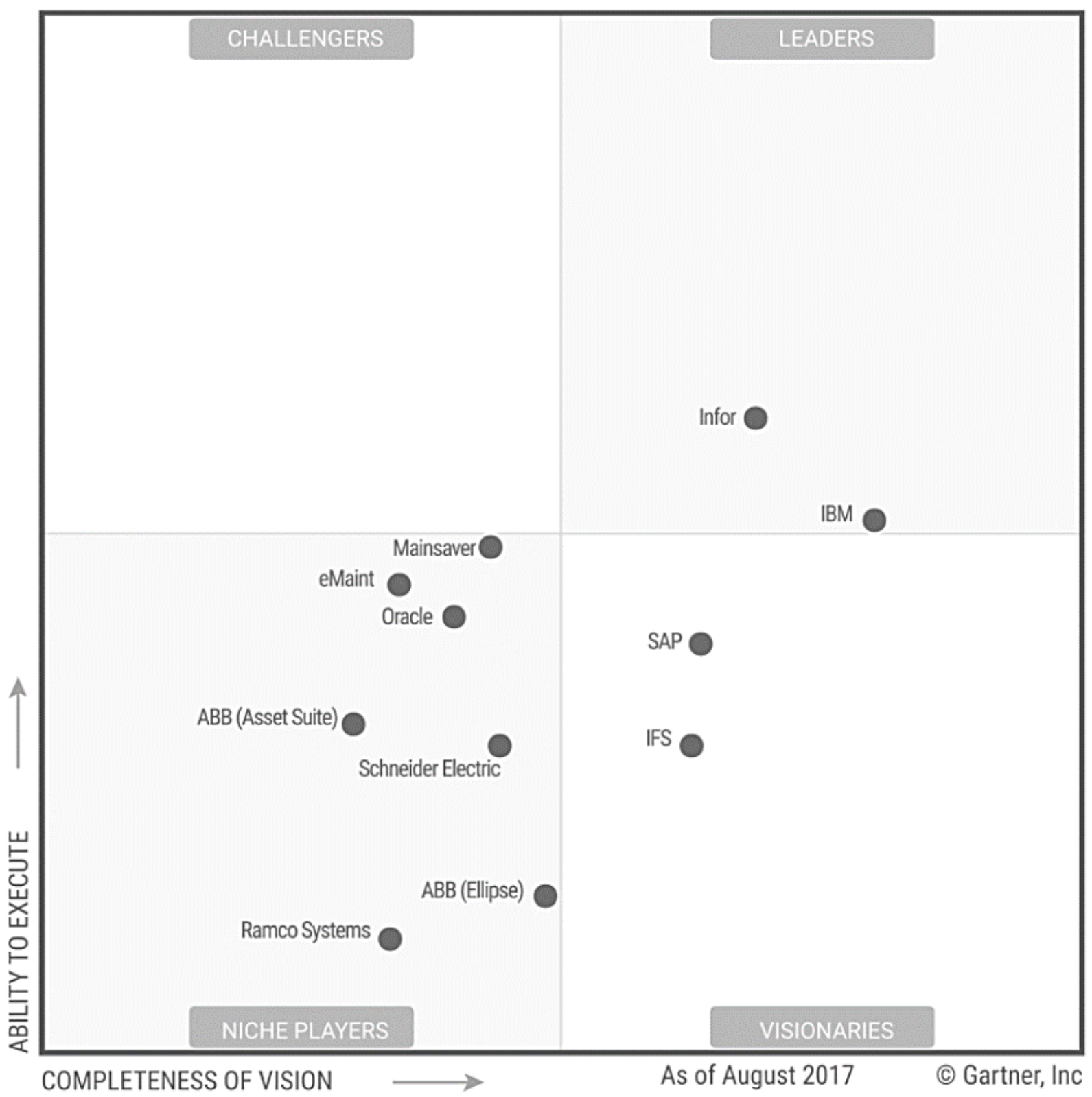

4. Magic A square of IT tools for managing technical assets [4]

Technical asset management systems are implemented by many infrastructure managers around the world. The software is also used by construction companies involved in infrastructure maintenance. The table presents a list of software suppliers and infrastructure managers who have implemented this type of software. 
Tab. 1. Summary of the implementation of EAM systems by infrastructure managers and maintenance companies Source: own study

\begin{tabular}{|c|c|c|}
\hline Software producer/name & $\begin{array}{l}\text { Railway infrastructure } \\
\text { manager }\end{array}$ & Country \\
\hline \multirow{10}{*}{$\begin{array}{l}\text { IBM } \\
\text { maximo }\end{array}$} & $\begin{array}{l}\text { Jernbaneverket (railway } \\
\text { infrastructure manager) }\end{array}$ & Norwway \\
\hline & $\begin{array}{l}\text { SNCF Réseau (railway } \\
\text { infrastructure manager) }\end{array}$ & France \\
\hline & $\begin{array}{l}\text { Российские железные } \\
\text { дороги - РЖД - Russian } \\
\text { railways }\end{array}$ & Russia \\
\hline & $\begin{array}{l}\text { Amtrak (railway } \\
\text { infrastructure manager) }\end{array}$ & the USA \\
\hline & $\begin{array}{l}\text { Kiwi Rail (railway } \\
\text { infrastructure manager) }\end{array}$ & New Zealand \\
\hline & $\begin{array}{l}\text { CNR - Country Region } \\
\text { Network (railway } \\
\text { infrastructure manager) }\end{array}$ & Australia \\
\hline & $\begin{array}{l}\text { SBB CFF FFS (railway } \\
\text { infrastructure manager) }\end{array}$ & Switzerland \\
\hline & $\begin{array}{l}\text { Slovenske zeleznice (railway } \\
\text { infrastructure manager) }\end{array}$ & Slovenia \\
\hline & $\begin{array}{l}\text { Companies carrying out } \\
\text { maintenance works }\end{array}$ & Country \\
\hline & BAM Rail & Netherlands \\
\hline \multirow{4}{*}{$\begin{array}{c}\text { ABB } \\
\text { Ellipse (EAM) } \\
\text { ABB }\end{array}$} & $\begin{array}{l}\text { Railway infrastructure } \\
\text { manager }\end{array}$ & Country \\
\hline & $\begin{array}{l}\text { Network Rail (railway } \\
\text { infrastructure manager) }\end{array}$ & the UK \\
\hline & $\begin{array}{l}\text { Brookfiield Rail (dawniej } \\
\text { WestNet Rail - railway } \\
\text { infrastructure manager) }\end{array}$ & Australia \\
\hline & $\begin{array}{l}\text { RailCorp (A company that } \\
\text { manages and maintains } \\
\text { Sydney's suburban and long- } \\
\text { distance rail infrastructure) }\end{array}$ & Australia (Sydney) \\
\hline \multirow{6}{*}{$\begin{array}{l}\text { Infor EAM } \\
\text { infor }\end{array}$} & $\begin{array}{l}\text { Railway infrastructure } \\
\text { manager }\end{array}$ & Country \\
\hline & $\begin{array}{l}\text { Căile Ferate Române CFR } \\
\text { (manager of the Romanian } \\
\text { railway network) }\end{array}$ & Romania \\
\hline & $\begin{array}{l}\text { Infraspeed (high speed rail } \\
\text { operator HLS-Zuid) }\end{array}$ & Netherlands \\
\hline & $\begin{array}{l}\text { FEPSA / SCP (infrastructure } \\
\text { manager - network and } \\
\text { trains) }\end{array}$ & Argentina \\
\hline & $\begin{array}{l}\text { Companies carrying out } \\
\text { maintenance works }\end{array}$ & Country \\
\hline & Asset Rail (one of the & Netherlands \\
\hline
\end{tabular}




\begin{tabular}{|c|c|c|}
\hline & $\begin{array}{l}\text { companies that keeps the } \\
\text { maintenance of the Dutch } \\
\text { railway infrastructure) }\end{array}$ & \\
\hline \multirow{3}{*}{$\begin{array}{c}\text { SAP } \\
\text { EAM/LAM }\end{array}$} & $\begin{array}{l}\text { Railway infrastructure } \\
\text { manager }\end{array}$ & Country \\
\hline & $\begin{array}{l}\text { ProRail (railway } \\
\text { infrastructure manager) }\end{array}$ & Netherlands \\
\hline & Queensland Rail & Australia \\
\hline \multirow{4}{*}{$\begin{array}{c}\text { MERIDIUM } \\
\text { MERIDIUM APM } \\
\text { (Asset Performance) } \\
\text { meridium }\end{array}$} & $\begin{array}{l}\text { Railway infrastructure } \\
\text { manager }\end{array}$ & Country \\
\hline & $\begin{array}{l}\text { Rete Ferroviaria Italiana } \\
\text { (railway infrastructure } \\
\text { manager) }\end{array}$ & Italy \\
\hline & $\begin{array}{l}\text { Firmy wykonujące prace } \\
\text { utrzymaniowe }\end{array}$ & Państwo \\
\hline & $\begin{array}{l}\text { Strukton Rail (one of the } \\
\text { companies that maintains the } \\
\text { Dutch railway infrastructure) }\end{array}$ & Netherlands \\
\hline \multirow{5}{*}{$\begin{array}{c}\text { OXAND } \\
\text { Simeo }^{\mathrm{TM}} \\
\text { (Asset Performance } \\
\text { Solution) } \\
\text { Simeo }\end{array}$} & $\begin{array}{l}\text { Railway infrastructure } \\
\text { manager }\end{array}$ & Państwo \\
\hline & $\begin{array}{l}\text { SBB CFF FFS (manager and } \\
\text { carrier) }\end{array}$ & Switzerland \\
\hline & $\begin{array}{l}\text { SNCF Réseau (railway } \\
\text { infrastructure manager) }\end{array}$ & France \\
\hline & $\begin{array}{l}\text { Infrabel (railway } \\
\text { infrastructure manager) }\end{array}$ & Belgium \\
\hline & $\begin{array}{l}\text { TPG (public transport } \\
\text { operator in Geneva) }\end{array}$ & Switzerland \\
\hline \multirow{6}{*}{$\begin{array}{l}\text { Mer Mec } \\
\text { - RAMSYS } \\
\text { (Railway Maintenance } \\
\text { Decision Support System) } \\
\text { - } \mathbf{R} \wedge \text { M S Y } \mathbf{S}^{\circ} \\
\text { INSPECTION } \\
\text { TECHNOLOGY } \\
\text { 1. SYSTEMS } \\
\text { RAMSYS }\end{array}$} & $\begin{array}{l}\text { Railway infrastructure } \\
\text { manager }\end{array}$ & Country \\
\hline & $\begin{array}{l}\text { Rete Ferroviaria Italiana } \\
\text { (railway infrastructure } \\
\text { manager) }\end{array}$ & Italy \\
\hline & $\begin{array}{l}\text { Mumbai Railway Vikas } \\
\text { Corporation, MVRC } \\
\text { (manager of a suburban } \\
\text { railway) }\end{array}$ & India \\
\hline & $\begin{array}{l}\text { Brookfield Rail (formerly } \\
\text { WestNet Rail - railway } \\
\text { infrastructure manager) }\end{array}$ & Australia \\
\hline & $\begin{array}{l}\text { Network Rail (railway } \\
\text { infrastructure manager) }\end{array}$ & the UK \\
\hline & $\begin{array}{l}\text { RailCorp (railway } \\
\text { infrastructure manager in the } \\
\text { south of Australia) }\end{array}$ & Australia \\
\hline \multirow{2}{*}{$\begin{array}{c}\text { ERDMANN } \\
\text { IRISSYS }{ }^{\circledR} \\
\text { International Railway } \\
\text { Inspection and Services }\end{array}$} & $\begin{array}{l}\text { Railway infrastructure } \\
\text { manager }\end{array}$ & Country \\
\hline & $\begin{array}{l}\text { ProRail (railway } \\
\text { infrastructure manager) }\end{array}$ & Netherlands \\
\hline
\end{tabular}




\begin{tabular}{|l|l|l|}
\hline \multicolumn{1}{|c|}{$\begin{array}{l}\text { System } \\
\text { IRISSYS }\end{array}$} & $\begin{array}{l}\text { Slovenske zeleznice d.d., } \\
\text { (manager and carrier) }\end{array}$ & Slovenia \\
\hline $\begin{array}{l}\text { Banedanmark (railway } \\
\text { infrastructure manager) }\end{array}$ & Denmark \\
\hline $\begin{array}{l}\text { Jernbaneverket (railway } \\
\text { infrastructure manager) }\end{array}$ & Norway \\
\hline $\begin{array}{l}\text { NetworkRail (railway } \\
\text { infrastructure manager) }\end{array}$ & the UK \\
\hline $\begin{array}{l}\text { HighSpeed1(HS1 high speed } \\
\text { line manager) }\end{array}$ & the UK \\
\hline $\begin{array}{l}\text { Israel Railways ltd (manager } \\
\text { and carrier) }\end{array}$ & Israel \\
\hline $\begin{array}{l}\text { Office National des Chemins } \\
\text { de Fer du Maroc (manager } \\
\text { and carrier) }\end{array}$ & Morocco \\
\hline $\begin{array}{l}\text { DB Netz AG (railway } \\
\text { infrastructure manager) }\end{array}$ & Germany \\
\hline $\begin{array}{l}\text { Zeleznice Srbije a.d. - a } \\
\text { joint-stock company of } \\
\text { Serbian railways }\end{array}$ & Serbia \\
\hline $\begin{array}{l}\text { Poccийские железныe } \\
\text { дороги - PЖД - Russian } \\
\text { railways }\end{array}$ & Russia \\
\hline $\begin{array}{l}\text { Liikennevirasto - Finnish } \\
\text { transport agency, manager of } \\
\text { railway, road and inland } \\
\text { transport infrastructure }\end{array}$ & Finland \\
\hline
\end{tabular}

Based on the analysis of available information on the above systems, a review of their functionality was made. Particularly important in the process of planning the development and maintenance of infrastructure, the features and functionalities of EAM systems can be divided into three main areas:

- data,

- analyzes and forecasts,

- decision support.

The following features and functionalities of the systems are particularly important in the data area:

- one source of information and a data repository - data on maintenance and security are managed within the system, the results of the celebrations, diagnostics and control can be jointly evaluated and evaluated,

- tools for importing existing data and collecting new data on elements of railway infrastructure (also directly from the area),

- entering data is carried out in an automated manner and at the same time the process is subject to control (the data covered are also modified),

- the ability to directly download data from various devices (including computers, from measuring vehicles, from mobile devices) thanks to which redundant paper documentation can be eliminated, there is no need to enter data into separate databases, which will start to speed up the circulation of information.

In the area of analyzes and forecasts: 
- ensuring physical and logical connection between infrastructure elements,

- a set of functions for storing, viewing, visualizing and analyzing the condition and efficiency of resources:

$>$ the ability to model infrastructure elements both as linear / spatial as well as point resources,

$>$ maps and reports (also graphic) containing an overview of the current technical condition,

$>$ easy and quick sorting and filtering of data,

$>$ linear / spatial or point reference for all properties (attributes),

- application of degradation models and forecasts of the maintenance of infrastructure elements,

- easy access to information on infrastructure elements that are necessary for exchange (material management for planned works),

- generating KPIs,

- prioritization of alarms and faults based on risk assessment,

- functionalities of geographic information systems (GIS) or integration with leading GIS systems,

- monitoring of ongoing maintenance works.

Supporting decisions:

- management of the life cycle of railway infrastructure elements,

- support for the identification and elimination of bottlenecks,

- simulations of maintenance scenarios and renovations, allows simulation of various scenarios, making it possible to ensure a balance between maintenance works and investments,

- budget preparation based on the history of the work performed, resource costs, the level of defects and on the basis of simulated scenarios in order to maintain the existing infrastructure and plan new investments,

- automatic transformation of diagnostic test results in a job / order request,

- functionalities for risk management and RAMS optimization (reliability, availability, maintainability, and safety),

- standardization and optimization of maintenance processes and knowledge transfer in the system,

- integrated and automated planning and monitoring of all work carried out and related costs of labor, materials and services, as well as their full transparency, including optimization of renovation costs.

\section{Summary}

Planning for the development and maintenance of infrastructure is a complex activity requiring consideration of many conditions not only of a technical and technological nature but also of a social, economic or demographic nature. The analyzed issue of systematic management of technical assets is against the need to support decision-making in the field of planning. The key areas of use and associated benefits are:

data area - up-to-date, reliable and available infrastructure data. It enables in the decisionmaking process the use of correct data, which thanks to a homogeneous structure can be efficiently and precisely compared and aggregated. Collecting data in one place also provides quick access, which is essential for their analysis during current business processes.

Analysis area - forecasting changes in infrastructure condition according to the planned scope of maintenance works. It enables the transition from making decisions mainly based on the current technical condition to forecasting changes in technical condition, taking 
into account differentiation factors related to intensity (eg traffic loads of different nature) or operating conditions (e.g. landform).

Decision support area - life cycle management of infrastructure elements and simulations of maintenance scenarios. They create conditions for moving away from the reactive action in the field of maintenance, for the pro-active decision to undertake these actions before the failure of a given infrastructure element occurs. They are also an indication to undertake investment activities if further intervention in the scope of maintenance and repairs would be unprofitable.

\section{Source materials}

[1] Biała księga „Strategia restrukturyzacji wspólnotowych kolei” - COM(96)421 wersja ostateczna z 30.7.1996 r.

[2] Dyrektywa Parlamentu Europejskiego i Rady 2012/34/UE z dnia 21 listopada 2012 r. w sprawie utworzenia jednolitego europejskiego obszaru kolejowego Dz.U. L 343 z 14.12.2012.

[3] EIM asset management working group „Good practice guide to asset management planning for rail infrastructure management”, 2014

[4] Gartner, Inc.

https://www.gartner.com/technology/research/methodologies/research_mq.jsp

[5] Międzynarodowy Związek Kolei (UIC), Guidelines for the Application of Asset Management in Railway Infrastructure Organisations, 2010

[6] Opracowanie Urzędu Transportu Kolejowego, Sprawozdanie ze stanu bezpieczeństwa ruchu kolejowego w 2016 r., Warszawa 2017

[7] PN-ISO 55000 Zarządzanie aktywami -- Informacje ogólne, zasady i terminologia

[8] Program wieloletni Pomoc w zakresie finansowania kosztów zarządzania infrastruktura kolejowa, w tym jej utrzymania i remontów do 2023 roku, Uchwała nr 7/2018 Rady Ministrów z dnia 16 stycznia 2018 r.

[9] www.plk-sa.pl 